\title{
The Metabolic Characterization of the Ciliate Protozoon Eudiplodinium medium from the Rumen of Buffalo
}

\author{
By M. A. NAGA AND K. EL-SHAZLY \\ Department of Animal Production, Faculty of Agriculture, University of \\ Alexandria, Egypt, U.A.R.
}

(Accepted for publication I6 April 1968)

\begin{abstract}
SUMMARY
An oligotrich protozoon identified as Eudiplodinium medium was separated in pure culture and inoculated into the rumen of an isolated ciliate-free buffalo (Bos bubalus L.) calf to act as a continuous source of the organism. Analysis of the protozoa showed that a single organism contained on average $3.35 \pm 0.003 \mu \mathrm{g}$. protein; the carbohydrate fraction $(49.1 \%$ of dry matter) gave on hydrolysis $60.4 \%$ glucose. Growth rate of the protozoa in vitro was dependent on food concentration. The number of protozoa was doubled in $2 \mathrm{hr}$ at a substrate concentration of $0.23 \mathrm{mg}$./protozoon; at lower concentrations the doubling time was greater; at higher concentrations $(0.32 \mathrm{mg} . /$ protozoon $)$ the organisms burst.

Eudiplodinium medium did not metabolize simple sugars; it utilized starch, amylopectin, amylose and showed highest activity with hemicelluloses. Xylans were degraded faster than arabans; xylans gave relatively lower amounts of volatile acids than did arabans; acetic and butyric acids predominated, formic acid and traces of propionic and lactic acids were found but no succinic acid. No cellulose digestion took place during incubation for $\mathrm{I} 2 \mathrm{hr}$; with longer periods of incubation with cellulose the organisms died. Ammonium salts, urea and amino acids were not used by the protozoa; proteolytic activity was observed towards gelatin, casein and gluten in descending order of activity. Cell-free extracts of $E$. medium showed activities towards carbohydrates as did whole organisms; xylanase activity was greatest. This enzyme was purified 28 -fold; it had an optimum $\mathrm{pH}$ of 7.5 and an optimum temperature of $43^{\circ}$.
\end{abstract}

\section{INTRODUCTION}

The present work is concerned with the isolation of a ciliate oligotrich protozoon, Eudiplodinium medium, from the rumen of buffalo (Bos bubalus L.). Under similar conditions of feeding, the numbers of this ciliate were greater in buffalo than in cow. The metabolism of this organism was then studied.

\section{METHODS}

Isolation of Eudiplodinium medium. Unsuccessful attempts were made to isolate this oligotrich by fractional sedimentation from long columns filled with buffer (Oxford, I95I); the sedimented organisms were contaminated with Entodinium. Isotricha species were destroyed by adding mannose (Abou Akkada \& Howard, 1960) to the medium. It was soon realized that Hungate medium (1942) was selective for Eudi- 
plodinium species. A strained rumen sample containing a complete protozoan population, obtained from a 4-month-old calf, was diluted I/Io by Hungate medium. Rye grass in Hungate medium was replaced by barley fodder (harvested at 30 days), dried and added to a final concentration of $0.08 \%(\mathrm{w} / \mathrm{v})$. The medium was renewed twice daily by sucking off the upper half of the liquor. Within 7 days, types of protozoa other than $E$. medium and $E$. neglectum had disappeared. $E$. medium was predominant in most inocula; $E$. neglectum did not survive the competition and disappeared. The pure culture of $E$. medium was used for inoculating an isolated ciliate-free buffalo calf so that it only harboured this oligotrich, which reached a reasonable count within Io days from inoculation. The calf was fed an early weaning concentrate mixture (Khoury, Ahmed \& El-Shazly, 1967) and a green fodder Lolium pereniale.

Preparation of suspensions of washed protozoa. Rumen samples were withdrawn from the experimental calf before feeding and the protozoa separated and washed as recommended by Oxford (195I). Chloramphenicol (50 $\mu \mathrm{g} . / \mathrm{ml}$.) was added to the last washings to decrease the number of bacteria; complete elimination of bacteria was not possible, but their activity was completely suppressed for a period of 18 to $22 \mathrm{hr}$ after the addition of chloramphenicol, as judged by complete lack of glucose fermentation during this period, after which glucose fermentation was resumed, unless a further dose of chloramphenicol was added. All fermentations were done within $12 \mathrm{hr}$ after adding chloramphenicol.

The counting technique. The in vitro growth rates were followed by counting protozoa in samples taken at different times. Since the number of protozoa in the cultures was small because of restricted sampling from the calf's rumen, an attempt was made to concentrate the protozoal content of a measured volume into one drop. The initial and final numbers of protozoa were counted in each treatment by withdrawing a $5 \mathrm{ml}$. sample from a known volume of the culture, under test by using a wide-mouthed graduated pipette. The pipette was left standing vertically for a few minutes until the protozoa contained in the sample sedimented to near the tip of the pipette. A small drop containing all the accumulated protozoa was then pipetted on to a slide and covered with a coverslip $(2 \cdot 3 \times 5 \cdot 1 \mathrm{~cm}$. $)$ so as to spread uniformly under it. Care was taken not to allow the formation of air bubbles. Counting was done at low power having a field area of $\mathrm{I} \mathrm{mm} .{ }^{2}$. In each slide 30 fields were counted. Three slides were prepared from each sample. This counting technique was simple and gave reproducible results having a coefficient of variability of $6.94 \%$ (ranging from 0.7 to $14 \%$ ). The slides were prepared in such a way as to have no more than $15^{-20}$ protozoa/field.

Metabolic activity. Washed protozoa in chloramphenicol $+\mathrm{CO}_{2}+$ buffer were distributed in $10 \mathrm{ml}$. samples into test-tubes containing a previously weighed amount of substrate. In all incubations the final substrate concentration was $0 \cdot 20 \%$. With each run an identical sample of protozoa-free supernatant fluid from the washed suspension was tested with a similar weight of substrate; this latter tube served as a control for detecting bacterial activity (Williams, Davis, Doetsch \& Gutierrez, I96r). Bacterial numbers were greatly decreased by the washing used and by the chloramphenicol; this confirms the findings of Coleman (1962, 1967).

All incubations were done at $40^{\circ}$ and lasted for $6 \mathrm{hr}$ with soluble sugars and $\mathrm{I} 2 \mathrm{hr}$ with polysaccharides and proteins. After saturation with $\mathrm{CO}_{2}$ the tubes were stoppered tightly with rubber bungs. After each run the viability of the protozoa was examined microscopically on a warm slide. At the end of each incubation period, the end pro- 
ducts in the supernatant fluid were determined and expressed as end product $/ \mathrm{mg}$. protozoal-N/hr.

The mono- and di-saccharides were of AR grade (British Drug Houses Ltd.); the polysaccharides were given by Dr Abou Akkada; amino acids, urea, ammonium sulphate and proteins were of GR grade (Merck).

The preparation of cell-free extracts. Cell-free extracts of protozoa were prepared according to Abou Akkada, Eadie \& Howard (1963) and kept under toluene in the refrigerator. It was checked for absence of bacteria by culturing in Coleman's media $a, b$, and c (1962) and found free.

Enzyme activities of cell-free extracts. One ml. citrate phosphate buffer, $0.05 \mathrm{~g}$. substrate in $0.5 \mathrm{ml}$. buffer solution and $0.2 \mathrm{ml}$. of cell-free extract were incubated for $\mathrm{I} h \mathrm{hr}$ to test for enzyme activities. Incubations were made at different $\mathrm{pH}$ values to find the optimum $\mathrm{pH}$ values.

Methods of analysis. Reducing sugars were estimated according to Somogyi (I945) with copper sulphate and Nelson's (1944) arsenomolybdate reagents. Sugars were identified on paper chromatograms according to the method of Trevelyan, Procter \& Harrison (1950). $R_{F}$ values were determined for all mono- or di-saccharides used or expected to result from hydrolysis of polysaccharides.

Organic acids were separated for individual determination on silica gel columns according to Bulen, Warner \& Burrell (1952) as modified by El-Shazly, Abou Akkada \& Naga (1963).

Proteolytic activity was followed colorimetrically by using the ninhydrin reagent (Hawk, Oser \& Summerson, 1953). A standard curve was plotted showing the relation between ninhydrin readings and nitrogen concentration of an amino acid mixture (casein acid-hydrolysate). Total $\mathrm{N}$ was determined by the micro-Kjeldahl technique (Chibnall, Rees \& Williams, 1943).

Urea was estimated by using soybean meal (British Drug Houses Ltd.) as a source of urease. Ammonia was measured by the microdiffusion technique (Conway, 1957).

Analysis of the protozoa. An acetone-dried mass of washed protozoa was used for determination of the cell composition. Protein $(\mathrm{N} \times 6 \cdot 25)$ was determined by the micro-Kjeldahl method. Lipids were extracted exhaustively with light petroleum $\left(40^{\circ}-60^{\circ}\right)$. For the determination of the carbohydrate fraction, proteins and polysaccharides were first dissolved in $30 \% \mathrm{NaOH}$ (Hungate, 1963); the cellulose and non-cellulose fractions were determined in the alcohol precipitate according to Abou Akkada et al. (1963) and Abou Akkada \& Howard (1960), respectively. The total sugar content was determined by the anthrone technique (Colvin, Attebery \& Ivy, 1961). Glucose was estimated by the specific technique of Hyvariner \& Nikkila (1962); this value was subtracted from the anthrone value to obtain the non-glucose sugar fraction.

The amino acid pattern of the protozoal protein was examined by using twodimensional paper chromatography in phenol-0.3\% $\mathrm{NH}_{3}$ and $n$-butanol+acetic acid + water $(40+10+50$ by vol.). Acid hydrolysis was done in sealed tubes with a $6 \mathrm{~N}-\mathrm{HCl}$ for $22-24 \mathrm{hr}$. Alkaline hydrolysis was done by boiling in saturated $\mathrm{Ba}(\mathrm{OH})_{2}$ solution for $2 \mathrm{hr}$. 


\section{RESULTS AND DISCUSSION}

Eudiplodinium medium (Awerinzew \& Mutafowa, 1914) was photographed and described by Hungate (I966) as 'one of the largest rumen protozoa... its macronucleus is depressed at two points on the dorsal side adjacent to the contractile vacuoles (Rees, 193I), it has two skeletal plates'. These morphological characteristics are typical of the species studied in the present work. A photograph of an iodinestained cell is shown in Pl. I, fig. I. Since it was difficult to obtain a clear photograph of the nucleus, the haematoxylin (Heidenhain) stain was applied to a specimen according to Gurr (1953); the stained nuclei are shown in Pl. I, fig. 2.

\section{The proximate cell composition of Eudiplodinium medium}

The proximate analysis of a mass of protozoa of $E$. medium showed the following composition ( $\%$ of dry matter): crude protein, $42 \cdot 3$; carbohydrates, $49 \cdot \mathrm{I}$; light petroleum extract, $7 \cdot 8$; ash $0 \cdot 8$. The protein content of this organism may appear somewhat high when compared with that of a mixed protozoal population (McNaught, Owen, Henry \& Kon, 1954). The authors ascribed the low protein content of their mixed protozoal preparation to its high content of stored polysaccharides; their protozoa had been separated from rumen samples obtained $2 \mathrm{hr}$ after feeding. In the present study, rumen samples were obtained before the morning ration, about $15 \mathrm{hr}$ after the last meal.

The carbohydrate fraction of $E$. medium gave on hydrolysis $60.4 \%$ glucose: the remaining 39.6 might have included pentoses from the nucleic acids.

The amino acid pattern of the protein fraction of this organism showed that glutamic and aspartic acids were predominant. The quantitative amino acid analyses of Weller (1957) and Purser \& Buechler (1966) showed these two acids to account for about $25 \%$ of the protozoal protein. The chromatograms from the acid and alkaline hydrolyses of some organisms showed the presence of all the essential amino acids. Tryptophan was not detected on the chromatograms.

Three suspensions containing about 2600,600 and 300 of Eudiplodinium organisms/ $\mathrm{ml}$. were found to contain $8.7 \mathrm{I}, 2.04$ and $0.98 \mathrm{mg}$. protein $/ \mathrm{ml}$. respectively; indicating that the protozoa contained $3.35 \pm 0.003 \mu \mathrm{g}$. protein/organism.

\section{Growth rates of Eudiplodinium medium}

Hungate (1942) obtained a culture containing over I000 organisms of Eudiplodinium neglectum $/ \mathrm{ml}$. at $0.08 \%(\mathrm{w} / \mathrm{v})$ feed concentration; increasing the substrate concentration favoured protozoal growth but the culture medium needed more frequent renewal. Cultures containing fewer protozoa and the same substrate concentration did not survive; it was suggested that this was because of the presence of toxic metabolic products. In the present cultures of $E$. medium the number of organisms never exceeded 50 to $100 / \mathrm{ml}$. with a feed concentration (barley hay) of $0.08 \%(\mathrm{w} / \mathrm{v})$. Even with as few protozoa as 5 to $\mathrm{ro} / \mathrm{ml}$. there was good growth, but only when the feed concentration did not exceed $0.23 \mathrm{mg}$./protozoa.

Table I shows the relationship between substrate concentration (barley hay) in $\mathrm{mg}$./protozoa and the growth of E. medium. A concentration of $0.23 \mathrm{mg}$. feed/protozoon was most favourable for growth. The initial number of protozoa was doubled within $2 \mathrm{hr}$, as compared with $\mathrm{I} 4$ and $7 \mathrm{hr}$ for the concentration of 0.08 and $0.16 \mathrm{mg}$. 
feed/protozoa, respectively. Higher concentrations ( $0.32 \mathrm{mg}$./protozoa) caused rupture of the organisms as observed microscopically. It is possible that the higher substrate concentrations per E. neglectum was the reason for their non-survival in the cultures of lower population densities prepared by Hungate (1942). On the other hand the longer generation time ( $48 \mathrm{hr}$ ) reported by Hungate (1942) was probably due to the much lower concentration of feed/protozoon $(0.0007 \mathrm{mg}$.) used in his culture. The different generation times reported for different protozoal species (Gutierrez, 1955, I959; Warner, I962; Coleman, I962; Mah, 1962) may have reflected limitations due to substrate concentration/organism rather than a character of the species.

Table I. The relationship between substrate concentration (barley hay in Hungate medium) (mg./protozoon) and the concentration of Eudiplodinium medium (organisms/ml.)

\begin{tabular}{|c|c|c|c|c|}
\hline \multirow{2}{*}{$\begin{array}{l}\text { Time from } \\
\text { start } \\
\text { (hr) }\end{array}$} & \multicolumn{4}{|c|}{ Substrate concentration (mg./protozoon) } \\
\hline & \multicolumn{4}{|c|}{ Protozoa (no./ml.)* } \\
\hline 0 & $10 \cdot 0$ & 50 & 4.4 & $2 \cdot 5$ \\
\hline I & 10.0 & $4 \cdot 8$ & 4.7 & $3 \cdot 3$ \\
\hline 2 & I I·4 & $5 \cdot 9$ & $9 \cdot 0$ & $2 \cdot 8$ \\
\hline 3 & I $2 \cdot 2$ & $7 \cdot 6$ & 13.9 & $2 \cdot 5$ \\
\hline 4 & $13 \cdot 0$ & $8 \cdot 4$ & $15 \cdot 7$ & - \\
\hline 5 & $13 \cdot 8$ & $9 \cdot 0$ & $17 \cdot 9$ & - \\
\hline 6 & $14^{\prime} I$ & $9 \cdot 6$ & $20 \cdot 6$ & 一 \\
\hline 7 & 14.9 & $9 \cdot 9$ & $20 \cdot 7$ & $I \cdot 8$ \\
\hline I I & $18 \cdot 3$ & $5 \cdot 7$ & $\mathrm{II} \cdot 2$ & 0.7 \\
\hline 14 & $20 \cdot 2$ & - & - & - \\
\hline
\end{tabular}

Table 2. Eudiplodinium medium: the exhaustion of stored polysaccharides of protozoa in presence of glucose

\begin{tabular}{|c|c|c|c|c|}
\hline \multirow[b]{2}{*}{ Time (hr) } & \multicolumn{2}{|c|}{ Glucose in medium } & \multicolumn{2}{|c|}{ Protozoal polysaccharides } \\
\hline & $\mu \mathrm{g} . / \mathrm{ml}$. & $\%$ of initial & $\mu \mathrm{g} . / \mathrm{ml}$. & $\%$ of initial \\
\hline 0 & $179 \cdot 0$ & $100 \cdot 0$ & $260 \cdot 0$ & $100 \cdot 0$ \\
\hline 4 & $184 \cdot 0$ & $102 \cdot 8$ & $182 \cdot 5$ & $70 \cdot 0$ \\
\hline 7 & $193 \cdot 0$ & $108 \cdot 0$ & 135.0 & $52 \cdot 0$ \\
\hline
\end{tabular}

The metabolic activities of Eudiplodinium medium

Eudiplodinium medium did not utilize glucose, fructose, mannose, galactose, xylose, arabinose, galacuronate, maltose, sucrose, lactose, cellobiose or xylobiose. The protozoa were alive and showed active movement at the end of the incubation period. It was observed that the sugar concentration in the supernatant fluid after incubation had increased; this must have come from stored polysaccharide in the organisms (Table 2). The protozoa became transparent after $6 \mathrm{hr}$ incubation with the soluble sugars; this is a sign of exhaustion of reserve material.

Eudiplodinium medium did not hydrolyse pectin, pectate, inulin, levan. Di- and poly-saccharides were run on paper chromatograms before and after incubation with $E$. medium; no new spots were observed after incubation. The ability of $E$. medium to engulf cellulose particles was observed microscopically, but no apparent utilization 
could be demonstrated. No sugars were released into the medium above that of the endogenous values, because of cellulose ingestion at $\mathrm{I} 2 \mathrm{hr}$ intervals. Incubations with cellulose for longer periods resulted in death of the organisms. Volatile fatty acid yield was somewhat higher $(0.079 \mu$-equiv./mg. protozoal-N/hr) in the cellulose incubations than in the controls. This might have been due to increased endogenous metabolism in the process of ingestion or to the presence of impurities (hemicellulose) in the cellulose preparation. Westphal (I934) observed the same species to ingest cellulose with no resulting deposition of polysaccharide reserves.

Table 3. Eudiplodinium medium: the soluble end-products of different polysaccharides fermented and the proportions (\%) of volatile fatty acids (VFA) produced, expressed as end-product/mg. protozoal-N/hr

\begin{tabular}{|c|c|c|c|c|c|c|c|}
\hline & $\begin{array}{l}\text { Reducing } \\
\text { sugar } \\
\text { produced }\end{array}$ & $\begin{array}{c}\text { Total VFA } \\
\text { produced } \\
\text { above }\end{array}$ & $\begin{array}{l}\text { Lactic acid* } \\
\text { produced } \\
\text { above }\end{array}$ & & Propo & ions of VFA & \\
\hline Polysaccharide & $\begin{array}{c}\text { genous } \\
(\mu \mathrm{g} . / \mathrm{mg} . \mathrm{N} / \mathrm{hr})\end{array}$ & $\begin{array}{l}\text { ( } \mu \text {-equiv./ } \\
\text { mg. N/hr) }\end{array}$ & $\begin{array}{l}\text { ( } \mu \text {-equiv./ } \\
\text { mg. N/hr) }\end{array}$ & $\begin{array}{l}\text { Formic } \\
\text { acid }\end{array}$ & $\begin{array}{l}\text { Acetic } \\
\text { acid }\end{array}$ & $\begin{array}{l}\text { Propionic } \\
\text { acid }\end{array}$ & $\begin{array}{c}\text { Butyric } \\
\text { acid }\end{array}$ \\
\hline Rice starch & $0.22 \pm 0.062$ & $0.43 \pm 0.031$ & 0.06 & $\begin{array}{l}24 \cdot 53 \\
25 \cdot 75\end{array}$ & $\begin{array}{l}42 \cdot 72 \\
43 \cdot 34\end{array}$ & $\begin{array}{l}4 \cdot 27 \\
3 \cdot 67\end{array}$ & $\begin{array}{l}28 \cdot 48 \\
27 \cdot 24\end{array}$ \\
\hline Amylose & $0.58 \pm 0.08 I$ & $0.38 \pm 0.040$ & $-\dagger$ & - & - & - & - \\
\hline Amylopectin & $0.96 \pm 0.010$ & $0.26 \pm 0.040$ & - & - & - & - & - \\
\hline Hemicellulose & $0.64 \pm 0.007$ & $0.34 \pm 0.036$ & 0.05 & $\begin{array}{l}18 \cdot 41 \\
16 \cdot 20\end{array}$ & $\begin{array}{l}54 \cdot 74 \\
59 \cdot 42\end{array}$ & $\begin{array}{l}3 \cdot 48 \\
3 \cdot 33\end{array}$ & $\begin{array}{l}23 \cdot 37 \\
21 \cdot 05\end{array}$ \\
\hline Xylan & $I .65 \pm 0.097$ & $0.02 \pm 0.001$ & 0.07 & $\begin{array}{l}33 \cdot 75 \\
32 \cdot 37\end{array}$ & $\begin{array}{l}46 \cdot 22 \\
45 \cdot 96\end{array}$ & $\begin{array}{l}3 \cdot 52 \\
3 \cdot 74\end{array}$ & $\begin{array}{l}15 \cdot 51 \\
17 \cdot 93\end{array}$ \\
\hline $\begin{array}{l}\text { Araban } \\
\text { Cellulose }\end{array}$ & $\begin{array}{l}0.06 \pm 0.003 \\
0.00\end{array}$ & $\begin{array}{l}0.34 \pm 0.079 \\
0.08 \pm 0.016\end{array}$ & - & - & - & - & - \\
\hline Endogenous & $0.01 \pm 0.004$ & $0.23 \pm 0.060$ & 0.05 & $\begin{array}{l}\mathrm{I} 2 \cdot 85 \\
\mathrm{II} \cdot \mathrm{I} 2\end{array}$ & $\begin{array}{l}57 \cdot 66 \\
56 \cdot 67\end{array}$ & $\begin{array}{l}4 \cdot 29 \\
4 \cdot 25\end{array}$ & $\begin{array}{l}25 \cdot 20 \\
27 \cdot 20\end{array}$ \\
\hline
\end{tabular}

Table 3 gives the products of metabolism of rice starch, amylose, amylopectin, hemicellulose, xylan, araban and cellulose. Starch and hemicellulose are the major sources of energy for this organism. Glucose and maltose were detected on chromatograms prepared from starch, amylose and amylopectin incubations. Xylose, arabinose or both were detected on paper chromatograms prepared from xylan and hemicellulose fermentations respectively.

Eudiplodinium medium is like other protozoa in the general pattern of end products, producing traces of propionic acid and much acetic and butyric acids (Howard, I963; Hungate, 1966). It also produces relatively large amounts of formic acid which seem to exceed that produced by any other rumen protozoa. Holotrichs do not produce formic acid (Heald \& Oxford, 1953; Gutierrez, 1955; Howard, 1959); Epidinium ecaudatum (Gutierrez \& Davis, 1962) and Entodinium caudatum (Abou Akkada \& Howard, 1960) produce little formic acid. Succinic acid was not found among the fermentation products of $E$. medium and only a little lactic acid (Table 3 ).

Xylan was hydrolysed mainly to xylose which was not further degraded appreciably to volatile fatty acids. This could be an example of the phenomenon of hydrolysis of a polymer without utilization of the products which was reported by Abou Akkada \& Howard (196I), who found that holotrichs hydrolysed pectic substances without utilizing the hydrolysis products. Dehority (1965) found that three strains of rumen 
cellulolytic bacteria degraded and utilized xylan, while five other organisms, particularly Bacteroides succinogenes, degraded it. The hydrolysis of xylan by E. medium may have significance for the growth of rumen bacteria. Xylose favours protein synthesis (Hendrickx \& Martin, 1963), an effect in this respect only surpassed by arabinose. In the present work xylose was not fermented and accumulated, arabinose (or perhaps the biose, as arabinose given externally is apparently not fermented) is fermented as fast as it is formed by hydrolysis of araban and does not accumulate.

\section{Nitrogen metabolism}

Urea and ammonium sulphate, in concentrations similar to that of artificial saliva (McDougall, 1948), were not utilized by E. medium even in the presence of amylopectin ( $0.2 \%)$. A mixture of 20 amino acids (in concentration as recommended by Quinn, Burroughs \& Christiansen, 1962) was not taken up or catabolized by this organism; no ammonia was produced when the organisms were incubated with the amino acid mixture for $6 \mathrm{hr}$. Abou Akkada \& Howard (1962) did not detect any utilization or degradation of Amino acids by E. caudatum by using similar techniques. Coleman \& Hall (1966) and Coleman (1967), using ${ }^{14} \mathrm{C}$-labelled amino acids, provided evidence of a slow uptake of amino acids by E. caudatum; some volatile fatty acids were found but not ammonia.

Table 4. Eudiplodinium medium: the end-products of different proteins with and without energy source (amylopectin)

\begin{tabular}{|c|c|c|}
\hline Protein substrate & $\begin{array}{l}\mathrm{NH}_{3} \text { produced } \\
\text { above the endo- } \\
\text { genous ( } \mu \mathrm{g} . \mathrm{NH}_{3}- \\
\mathrm{N} / \mathrm{mg} \text {. protein-N/ } \\
\text { hr) }\end{array}$ & $\begin{array}{l}\text { Amino acids pro- } \\
\text { duced above endo- } \\
\text { genous ( } \mu \mathrm{g} \text {. amino- } \\
\mathrm{N} / \mathrm{mg} \text {. protein-N/ } \\
\mathrm{hr} \text { ) }\end{array}$ \\
\hline Endogenous & 0.48 & $19 \cdot 62$ \\
\hline Endogenous + amylopectin & - & $6 \cdot 65$ \\
\hline Casein alone & - & $26 \cdot 00$ \\
\hline Casein + amylopectin & - & $45 \cdot 00$ \\
\hline Ground casein + amylopectin & - & $14 \cdot 32$ \\
\hline Gluten + amylopectin & - & $17 \cdot 00$ \\
\hline Ground gluten + amylopectin & - & II $\cdot 09$ \\
\hline Gelatin alone & - & $39 \cdot 2 \mathrm{I}$ \\
\hline Gelatin + amylopectin & - & $58 \cdot 36$ \\
\hline
\end{tabular}

Eudiplodinium medium produced ammonia and amino acids as end-products of endogenous $\mathrm{N}$ metabolism; the presence of amylopectin increased metabolic activity as indicated by higher amino acid production (Table 4). The addition of cysteine $\mathrm{HCl}$ $(2 \%)$ favoured proteolysis and was used in all experiments. Gelatin showed the highest rate of hydrolysis followed by casein. Gluten was the least hydrolysable (Table 4). It appeared that the rate of protein breakdown by $E$. medium ran parallel with the solubility of the protein. The addition of amylopectin to the protein increased proteolysis significantly. However, the proteolytic power of E. medium was much lower than that of E. caudatum (Abou Akkada \& Howard, 1962). When casein and gluten were finely ground, proteolysis was considerably decreased (Table 4). 


\section{Activity of cell-free extracts of Eudiplodinium medium}

Cell-free extracts of holotrichs were shown to exhibit activities corresponding to those of the whole living protozoa (Howard, 1959). Howard (1963) reported that the holotrich outer membrane was permeable, while that of oligotrichs was not. The cellfree extracts of oligotrichs seem to lack this parallelism in activity with the whole protozoa. Sugden (1953) and Howard (1963) reported that oligotrichs fermented only the insoluble particulated polysaccharides, and did not utilize soluble carbohydrates. The cell-free extracts of oligotrichs exhibited enzymic activities against soluble disaccharides (maltose, sucrose, cellobiose, xylobiose; Abou Akkada \& Howard, 1960, I962; Bailey \& Clarke, I963). On the other hand, there were enzymes detected in living protozoa which were not found in the corresponding cell-free extracts (Bailey \& Howard, 1962; Bailey \& Clarke, 1963). The cell-free extract of E. medium showed no proteinase activity which was observed with the living protozoa. Maltose and xylobiose were hydrolysed by the cell-free extracts of $E$. medium to a very small extent (about $8 \%$ ).

Table 5. Eudiplodinium medium cell-free extract: the specific activity of xylanase in the different ammonium sulphate precipitate fractions of the cell-free extract

The incubations lasted for $30 \mathrm{~min}$. at $40^{\circ}$. Incubation mixture was: $2 \mathrm{mg}$. xylan added as $0.2 \mathrm{ml}$ of $\mathrm{I} \%$ solution $+0.2 \mathrm{ml}$. cell-free extract and phosphate + citrate buffer $(\mathrm{pH} 7)$.

Crude cellfree extract

33.4
Ammonium sulphate (\%) precipitate

\begin{tabular}{|c|c|c|c|c|c|}
\hline IO & 20 & 30 & 40 & 50 & 60 \\
\hline \multicolumn{6}{|c|}{ Xylose producte $(\mu \mathrm{g} . / \mathrm{mg} . \mathrm{N} / \mathrm{min})}$. \\
\hline 20.9 & $19 \cdot 0$ & $218 \cdot 0$ & $634 \cdot 2$ & $938 \cdot 3$ & 389.0 \\
\hline
\end{tabular}

Figure I shows the relationship between $\mathrm{pH}$ value and xylanase, $\mathrm{I}-4-\alpha$-gluconidase, I-6- $\alpha$-glucosidase and arabinase activities, when tested under the same conditions. The activities in the cell-free extract of $E$. medium followed the same trend as the activities of the living protozoa (Table 3 ). The enzymes concerned with hemicellulose degradation (xylanase, arabinase) had different $\mathrm{pH}$ optima ( $7 \cdot 5$ and $5 \cdot 5$, respectively). The amylases had an optimum $\mathrm{pH}$ about 6.

Partial purification of the xylanase was effected by using different concentrations of saturated ammonium sulphate. Table 5 shows xylanase specific activity ( $\mu \mathrm{g}$. xylose produced $/ \mu \mathrm{g}$. $\mathrm{N} / \mathrm{min}$.) of the crude cell-free extract and in the different ammonium sulphate precipitated fractions. The highest specific activity was found in the $50 \%$ ammonium sulphate precipitate which showed a $28 \cdot 7$-fold purification. Optimum $\mathrm{pH}$ values and temperature values obtained with the crude preparation were similar to those obtained with the purified preparation (Fig. I, 2).

Xylanase activity of rumen liquor (Sorensen, 1955), rumen bacteria (Howard, Jones \& Purdom, 1960) and of Fusarium roseum (Gascoigne \& Gascoigne, 1960) have been studied; their respective $\mathrm{pH}$ values were found to be $6.3,5.6$ and 6.3 . Three attempts were made to determine Michaelis constant of the enzyme xylanase from $E$. medium. Solubilized xylan (treated with hot $0 \cdot \mathrm{I} \mathrm{N}-\mathrm{HCl}$ ) was used; the results were not reproducible. Howard et al. (1960) found that xylanase activity of rumen bacteria 


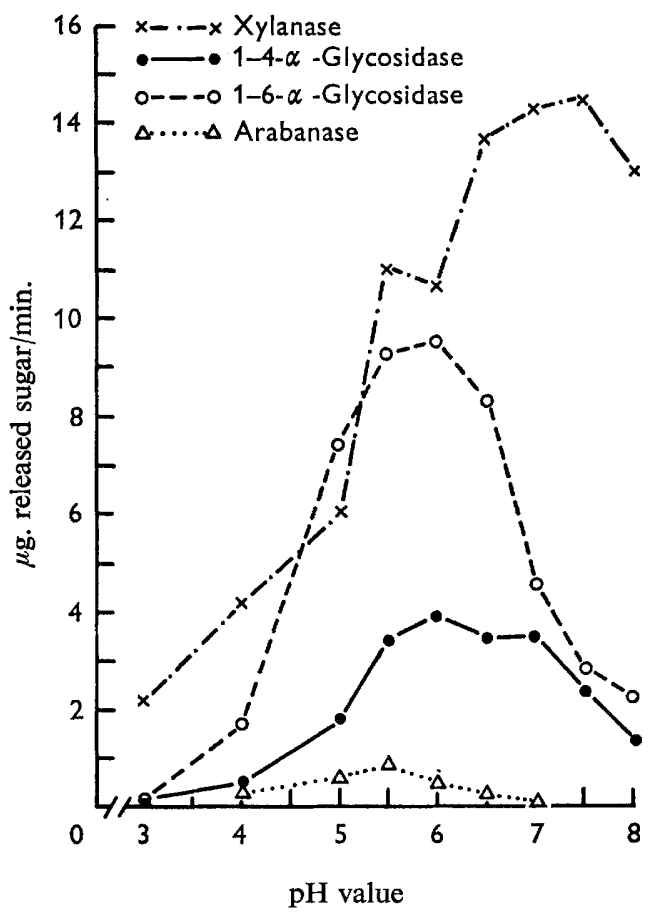

Fig. I. The pH-activity relationship of enzymes in cell-free extract of Eudiplodinium medium. Incubations at $40^{\circ}$ for I hr. Incubation mixture: $2 \mathrm{mg}$. substrate added as in $0.2 \mathrm{ml}$. cell-free extract (crude); $0.6 \mathrm{ml}$. phosphate + citrate buffer of different $\mathrm{pH}$ values.

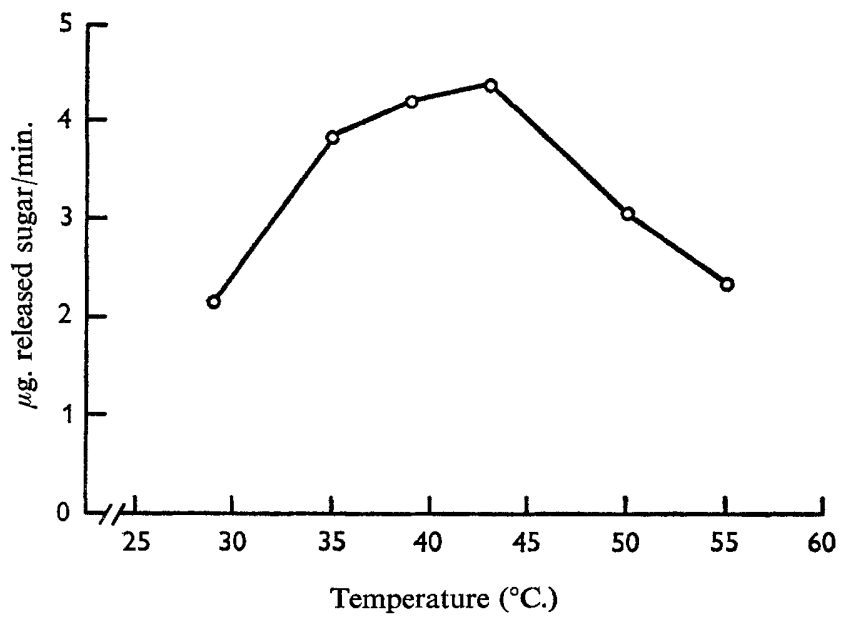

Fig. 2. Eudiplodinium medium cell-free extract. The temperature-activity relationship of the enzyme xylanase. Incubations for $\mathrm{I} \mathrm{hr}$ at different temperatures. Incubation mixtures consisted of: $2 \mathrm{mg}$. xylan added as $0.2 \mathrm{ml}$. of a $\mathrm{I} \%$ solution; $0.2 \mathrm{ml}$. cell-free extract; $0.6 \mathrm{ml}$. phosphate + citrate buffer ( $\mathrm{pH}_{7}$ ). 
decreased sharply as the degree of polymerization of the xylan was decreased, and reported that 'the reducing power of the enzyme + pentosan mixture became constant at a value suggesting that the pentosan had been broken down to oligosaccharides with degree of polymerization of about 12 '.

In the present work when the prepared soluble xylan fraction was completely hydrolysed, it had a reducing power 13 times as great as before hydrolysis, suggesting a degree of polymerization of $\mathrm{I} 3$ units for the solubilized xylan fraction. From this point of view, the short-chain xylan preparation was not expected to respond as native xylan to the enzyme action. The enzyme action on this substrate ceased on hydrolysing $64 \%$ of its structure.

\section{REFERENCES}

Abou AkKada, A. R. \& Howard, B. H. (1960). The biochemistry of rumen protozoa. 3. The carbohydrate metabolism of Entodinium. Biochem. J. 76, 445.

ABou AKKadA, A. R. \& Howard, B. H. (I961). The biochemistry of rumen protozoa. 4. The decomposition of pectic substances. Biochem. $J .78,512$.

Abou AKKadA, A. R. \& Howard, B. H. (1962). The biochemistry of rumen protozoa. 5. The nitrogen metabolism of Entodinium. Biochem. J. 82, 313 .

ABou AKKadA, A. R., EADIE, J. M. \& Howard, B. H. (1963). The biochemistry of rumen protozoa. 7. The carbohydrases of Polyplastron multivesiculatum. Biochem. J. 89, 268.

Awerinzew, S. \& Mutafowa, R. (1914). Quoted by Hungate, R. E. (1966).

Bailey, R. W. \& Howard, B. H. (I962). Preparation of enzymes from rumen protozoa by indole disintegration. Archs. Biochem. Biophys. 99, 299.

Bailey, R. W. \& ClARKE, R. T. J. (1963). Carbohydrases activity of rumen Entodinium species from sheep on starch-free diet. Nature, Lond. 198, 787.

BULEN, W. A., WARNER, J. E. \& BURRELL, R. C. (1952). Separation of organic aids from plant tissues. Analyt. Chem. 24, 187.

Chibnall, A. C., Rees, M. W. \& Williams, E. F. (1943). The total nitrogen content of egg albumin and other proteins. Biochem. J. 37, 354.

Coleman, G. S. (1962). The preparation and survival of almost bacteria-free suspensions of Entodinium caudatum. J. gen. Microbiol. 28, 271.

Coleman, G. S. (1967). The metabolism of free amino-acids by washed suspensions of the rumen ciliate Entodinium caudatum J. gen. Microbiol. 47, 433.

Coleman, G. S. \& Hall, F. J. (1966). The digestion of bacteria by the rumen ciliate Entodinium caudatum. Proc. Soc. gen. Microbiol. 44, iii.

Colvin, H. W., Attebery, J. T. \& Ivy, J. T. (1961). Comparison of the anthrone reagent and a copper reduction method for determining blood sugar in calves. J. Dairy Sci. 44, 208 r.

Conway, E. J. (1957). Microdiffusion Analysis and Volumetric Error. $4^{\text {th }}$ ed. London: Crosby Lockwood and Son Ltd.

DeHority, B. A. (1965). Degradation and utilization of isolated hemicellulose by pure cultures of cellulolytic rumen bacteria. J. Bact. 89, I5I5.

GasCoIGNE, J. A. \& GASCOIGNE, M. M. (1960). The xylanase of Fusarium roseum. J. gen. Microbiol. 12, 242.

GurR, E. (1953). A Practical Manual of Medical and Biological Staining Techniques. London: Leonard Hill Ltd.

GutierREZ, J. C. (1955). Experiments on the culture and physiology of holotrichs from the bovine rumen. Biochem. J. 60, 516.

Gutierrez, J. C. (1959). Studies on the culture of ciliate Epidinium ecaudatum Crawley. J.Protozool. 6 (suppl.), 2 I.

GutierRez, J. C. \& Davis, R. E. (1962). Culture and metabolism of the rumen ciliate Epidinium ecaudatum Crawley. Appl. Microbiol. 10, 305.

Hawk, P. B., Oser, B. L. \& Summerson, W. H. (1953). Practical Physiological Chemistry. London: J. and A. Churchill. 



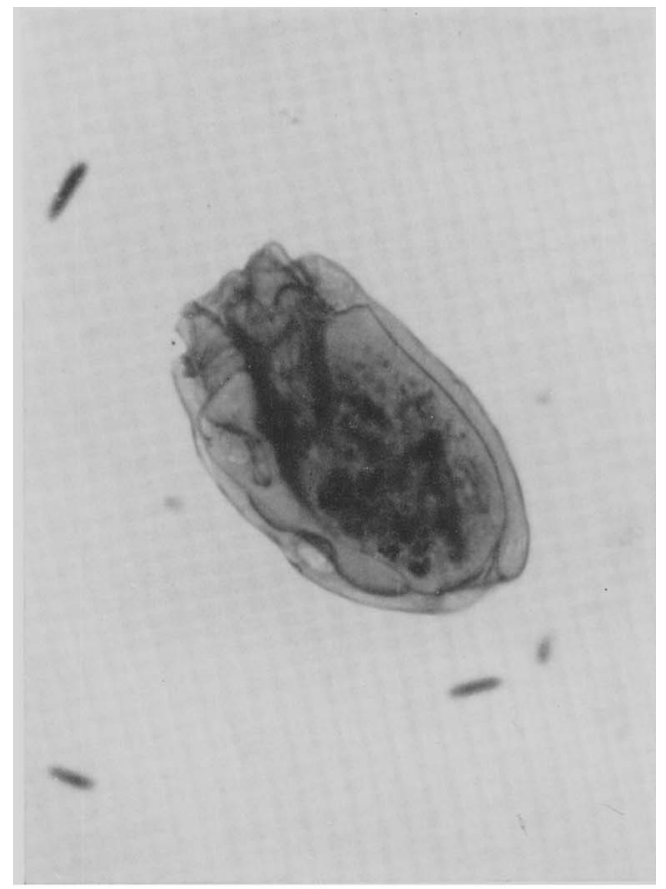

Fig. I

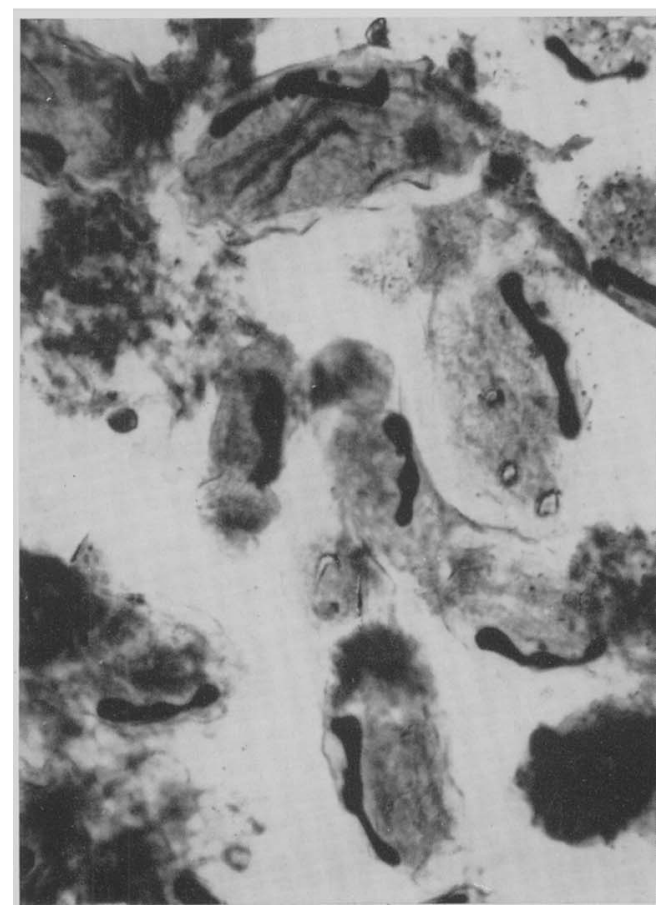

Fig. 2 
Heald, P. T. \& OxFord, A. E. (1953). Fermentation of soluble sugars by anaerobic holotrich ciliates of the genera Isotricha and Dasytricha. Biochem. J. 35, 506.

Hendrickx, H. \& Martin, J. (1963). C. r. Rech. Inst. Encour. Rech. scient. Ind. Agric. 3r, I IO.

HowARD, B. H. (1959). The biochemistry of rumen protozoa. 2. some carbohydrases in cell-free extracts of Dasytrichia and Isotricha. Biochem. J. 7r, 675.

HowARD, B. H. (1963). Metabolism of carbohydrates by rumen protozoa. Biochem. J. 89, 89.

Howard, B. H., Jones, G. \& PURDom, M. R. (1960). The pentosans of some rumen bacteria. Biochem. $J .74,173$.

HuNGATE, R. E. (1942). The culture of Eudiplodinium neglectum with experiments on the digestion of cellulose. Biol. Bull. mar. biol. Lab., Woods Hole 83, 303.

Hungate, R. E. (1963). Polysaccharide storage and growth efficiency in Ruminococcus albus. J. Bact. $86,848$.

Hungate, R. E. (1966). The Rumen and Its Microbes. New York: Academic Press.

Hyvariner, A. \& NikKILA, E. A. (I962). Specific determination of blood glucose with $o$-toluidine. Nutr. Abst. Rev. 32, 689.

KhouRY, F. K., AHMED, I. A. \& EL-ShazLY, K. (1967). Early weaning in cow and buffalo calves (Bos bubalus, L.) I. Growth rates, efficiency of feed utilization and cost of unit gain. J. Dairy Sci. 5o, I66I.

MAH, R. A. (1962). Experiments on the culture and physiology of Ophryoscolex purknei. Ph.D. thesis, University of California, Davis, California.

McDougall, E. I. (1948). Studies on ruminant saliva. I. The composition and output of sheep's saliva. Biochem. J. 43, 99.

McNaught, M. L., Owen, E. C., Henry, K. M. \& Kon, S. K. (1954). The utilization of non-protein nitrogen in the bovine rumen. 8 . The nutritive value of the proteins of dried rumen bacteria, rumen protozoa and brewers yeast for rats. Biochem. $J .56,15 \mathrm{I}$.

Nelson, N. (1944). A photometric adapation of the Somogyi method for the determination of glucose. J. biol. Chem. 153, 375.

OXFord, A. E. (195I). The conversion of certain soluble sugars to a glucosan by holotrich ciliates in the rumen of sheep. J. gen. Microbiol. $\mathbf{5}, 83$.

Purser, D. B. \& BUeChler, S. M. (1966). Amino-acid composition of rumen organisms. J. Dairy Sci. 49, 8I.

QuinN, L. Y., Burroughs, W. \& Christiansen, W. C. (1962). Continuous culture of ruminal microorganisms in chemically defined medium. 2. Culture medium studies. Appl. Microbiol. ro, 583.

Rees, C. W. (I93I). Quoted by Hungate, R. E. (1966).

El-Shazly, K., Abou AkKadA, A. R. \& NAGA, M. A. (1963). The use of the in vitro fermentation technique to estimate the digestible energy content of some Egyptian forages. 2. The in vitro production of total VFA and organic acids as criteria of energy content. J. agric. Sci. 6r, 109.

Somogyi, M. (1945). A new reagent for the determination of sugar. J. biol. Chem. 160, 6I.

Sorensen, H. (1955). Xylanase in the soil and the rumen. Nature, Lond. 176, 74.

SugDEN, B. (I953). The cultivation and metabolism of oligotrich protozoa from sheep's rumen. J. gen. Microbiol. 9, 44.

Trevelyan, W. E., Procter, D. P. \& Harrison, J. S. (1950). Detection of sugars on paper chromatograms. Nature, Lond. I66, 444.

WARNER, A. C. I. (1962). Some factors influencing the rumen microbial population. J. gen. Microbiol. 28, 129.

WeLLER, R. A. (1957). The amino acid composition of hydrolysates of microbial preparations from sheep. Aust. J. biol. Sci. ro, 384.

WestPhal, A. (1934). Quoted by Hungate, R. E. (1966).

Williams, P. P., Davis, R. E., Doetsch, R. N. \& Gutierrez, J. (196I). Physiological studies of the rumen protozoan Ophyroscolex caudatus Eberlein. Appl. Microbiol. 9, 405.

\section{EXPLANATION OF PLATE}

Fig. I. Eudiplodinium medium from the rumen of buffalo stained with iodine. $\times 160$.

Fig. 2. Eudiplodinium medium from the rumen of buffalo. Stained with haematoxylin to show the macronucleus. $\times 99$. 